\title{
Hubungan Perilaku Perawatan Rambut Terhadap Kejadian Dermatitis Seboroik pada Siswi SMA Muhammadiyah 1 Semarang
}

\section{Corelation Behavior of Hair Treatment to Occurrence of Seborrhoeic Dermatitis at SMA Muhammadiyah 1 Semarang}

\author{
Bevi Ayu ${ }^{1}$, Retno Indrastiti², Kanti Ratnaningrum ${ }^{3}$ \\ 1) Mahasiswa Program Studi Pendidikan Dokter, Fakultas Kedokteran, Universitas Muhammadiyah \\ Semarang \\ 2) Bagian Ilmu Kesehatan Kulit dan Kelamin, Fakultas Kedokteran Universitas Muhammadiyah Semarang \\ 3)Bagian Ilmu Penyakit Tropis, Fakultas Kedokteran Universitas Muhammadiyah Semarang \\ Fakultas Kedokteran Universitas Muhammadiyah Semarang. \\ Jl. Wonodri Sendang Raya 2A, Semarang. Email: beviayukumala@gmail.com
}

\begin{abstract}
Abstrak
Latar Belakang :Dermatitis seboroik terjadi pada setengah populasi global remaja dan pasca-pubertas. Dermatitis seboroik menjadi salah satu masalah pada pengguna hijab, oleh karena itu peneliti ingin mengetahui perilaku perawatan rambut terhadap kejadian dermatitis seboroik pada siswi SMA Muhammadiyah 1 Semarang.

Metode : Penelitian ini merupakan observasional analitik dengan pendekatan cross sectional. Pengambilan sampel menggunakan rumus slovin dengan teknik simpel random sampling. Populasi sampel merupakan Siswi SMA Muhammadiyah 1 Semarang kelas 2 dan kelas 3 dengan kriteria inklusi siswi yang konsisten menggunakan hijab selama berada di sekolah dan di kehidupan sehari - hari , siswi berusia 15 - 17 tahun, sedangkan kriteria ekslusi meliputi siswi yang menderita penyakit kulit bagian kepala seperti Tinea Capitis, Psoriasis, Alopecia Areata, dan Pedikulosis, serta siswi yang pernah mengalami post trauma pada kepala (Trikotilomania, Alopecia dan siswi yang mengalami post operasi pada kepala. Data penelitian menggunakan data primer dengan pemeriksaan fisik menggunakan loop dan wawancara dengan kuesioner. Uji statistik penelitian menggunakan uji chi-square dan regresi logistik.

Hasil : Dari 66 siswi, didapatkan hasil bahwa 84,8\% (50 siswi) mengalami dermatitis seboroik. Pengunaan handuk $(\mathrm{p}=0,016 ; \beta=3,429)$, frekuensi mengganti handuk $(\mathrm{p} 0,022 ; \beta=2,678)$, dan cara menyimpan handuk $(p=0,018 ; \beta=2,829)$ berpengaruh pada kejadian dermatitis seboroik
\end{abstract}

Simpulan : Terdapat hubungan yang signifikan antara perilaku perawatan rambut terhadap dermatitis seboroik pada siswi SMA Muhammadiyah 1 Semarang.

Kata kunci: dermatitis seboroik, higiene perorangan, perilaku perawatan rambut, tempat penyimpanan hijab. 


\section{Abstract}

Background: Seborrhoeic dermatitis occurs in half the global population of post-puberty adolescents. Seborrhoeic dermatitis is one of the problems in hijab users, therefore researchers want to know behavior of hair treatment to the occurrence of seborrheic dermatitis in students of High School Muhammadiyah 1 (SMA Muhammadiyah 1) Semarang.

Method: an analytic observational study with cross sectional. Sampling using slovin formula with simple random sampling technique. The sample population is students of SMA Muhammadiyah 1 Semarang class 2 and 3 with inclusion criteria consistent by using hijab during school and everyday life, female students aged 15-17 years; exclusion criteria include students suffering from skin diseases of the head such as Tinea Capitis, Psoriasis, Alopecia Areata, and Pediculosis; and students who have experienced post trauma to the head (Trichotillomania, Alopecia) and postoperative students on the head. Research data using primary data by physical examination using loop and interview with questionnaire. The research statistic used chisquare test and logistic regression.

Results: From 66 female students, it was found that 84.8\% (50 girls) had seborrheic dermatitis. use of towel $(\mathrm{p}=0.016 ; \beta=3.429)$, the frequency of towel replacing $(\mathrm{p} 0.022 ; \beta=2,678)$, and the way of towel $(\mathrm{p}$ $=0,018 ; \beta=2,829)$ had significant on occurrence of seborrhoeic dermatitis.

Conclusion: There is a significant relationship between hair treatment behavior against seborrheic dermatitis in high school students of Muhammadiyah 1 Semarang.

Keywords: seborrhoeic dermatitis, individual hygiene, hair-care behavior, hijab storage.

\section{PENDAHULUAN}

Dermatitis seboroik atau yang disebut dengan ketombe dialami pada $50 \%$ populasi global remaja pasca-pubertas, serta dapat dialami pada semua etnis dan jenis kelamin(1). Derajat keparahan dermatitis seboroik dipengaruhi oleh usia terutama masa pubertas dan usia menengah.(2,3) Dermatitis seboroik merupakan masalah pada kulit kepala yang sering diderita perempuan pengguna hijab.(3)

Indonesia merupakan negara dengan mayoritas penduduk muslim (87,18\%) dengan masalah kesehatan yang timbul seperti dermatitis seboroik perbandingan perempuan lebih banyak dari laki laki.(4) Terdapat beberapa faktor yang menyebabkan dermatitis seboroik, yaitu kolonisasi Malasseria.sp, peningkatan produksi sebum dan faktor predisposisi pada individu.(5) Permasalahan pada pengguna hijab dapat terjadi karena sikap yang erat kaitannya dengan kelembapan dan panas akibat pola perawatan rambut yang salah dan penggunaan hijab yang tidak benar.(6) Beberapa faktor yang dapat mempengaruhi kesehatan kulit kepala, diantaranya adalah stres lingkungan, misalnya iklim, musim, kolonisasi mikroba dan perubahan hormonal. Faktor lain yang dapat meningkatkan terjadinya dermatitis seboroik diantaranya yaitu usia, higiene kulit, stress, dan pengguna hijab. (7)

Penggunaan hijab pada dasarnya bukanlah menjadi penyebab dari terganggunya kesehatan rambut, namun sikap dalam menjaga kesehatan rambutlah yang harus diperhatikan karena dapat menjadi penyebab munculnya permasalahan rambut.(8,9) Dari adanya masalah yang timbul pada pengguna hijab, peneliti ingin mengetahui hubungan perilaku perawatan rambut pada perempuan berhijab terhadap kejadian dermatitis seboroik pada siswi SMA Muhammadiyah 1 Semarang. 


\section{METODE PENELITIAN}

Penelitian ini menggunakan study observasional analitik dengan pendekatan cross sectional. Pengambilan sampel dilakukan menggunakan rumus Slovin dengan teknik simpel random sampling. Populasi sampel merupakan Siswi SMA Muhammadiyah 1 Semarang kelas 2 dan kelas 3 dengan kriteria inklusi siswi yang konsisten menggunakan hijab selama berada di sekolah dan di kehidupan sehari - hari , siswi berusia 15 - 17 tahun, sedangkan kriteria ekslusi meliputi siswi yang menderita penyakit kulit bagian kepala seperti Tinea Capitis, Psoriasis, Alopecia Areata, dan Pedikulosis, serta siswi yang pernah mengalami post trauma pada kepala (Trikotilomania, Alopecia) dan siswi yang mengalami post operasi pada kepala.

Data yang dikumpulkan dalam penelitian ini merupakan data primer dengan pemeriksaan fisik menggunakan loop dan wawancara menggunakan kuesioner . Pemeriksaan dengan loop dilakukan dengan memeriksa rambut siswi satu persatu dikatakan dermatitis seboroik bila ditemukan bentuk besar - besar seperti sisik - sisik, disertai dengan adanya kotoran - kotoran yang berlemak, rasa gatal dan kerontokan rambut yang berlebihan. Validasi kuesioner diuji dengan validasi expert, reliabilitas diuji dengan test-retest dan kesesuaiannya diuji dengan kappa yang digunakan untuk menentukan bigiene perorangan siswi. Analaisis menggunakan analisis bivariat dengan uji chi-square dan analisis multivariat menggunakan regresi logistik.

\section{HASIL PENELITIAN}

Dari 66 sampel yang diikutkan dalam analisis di dapatakan hasil lebih dari 50\% sampel tidak keramas setiap minggu sebesar 34 orang (51,5\%), keramas tidak dengan shampo sebesar 46 orang (69,7\%), berganti-ganti shampoo sebesar 47 orang $(71,2 \%)$, menggunakan handuk sendiri sebesar 35 orang (53,0\%), mengganti handuk 5 hari sekali sebesar 51 orang $(77,3 \%)$, menggunakan sisir bergantian sebesar 52 orang (78,8\%), mengganti hijab setiap 2-3 hari sebesar 35 orang (53\%), dan yang menyimpan hijab kurang terkena cahaya sebesar 36 orang (54,5\%). Hampir seluruh sampel menggunakan hijab bergantin 65 orang $(98,5 \%)$ (tabel 1).

\section{a. Analisis Bivariat}

Dari hasil analisis bivariat diketahui bahwa frekuensi keramas setiap minggu, kebiasaan berganti-ganti shampoo, penggunaan handuk, frekuensi mengganti handuk, penggunaan sisir bergantian, dan cara menyimpan hijab merupakan faktor ynag signifikan terhadap terjadinya dermatitis seboroik (tabel 2).

Frekuensi keramas $\leq 1$ kali setiap minggu signifikan terhadap terjadinya dermatitis seboroik $\quad(p=0,041 ; \quad P R=5,333), \quad$ kebiasaan berganti-ganti shampoo signifikan terhadap terjadinya dermatitis seboroik $(p=0,027$; $\mathrm{PR}=4,962$ ), penggunaan handuk bergantian signifikan terhadap terjadinya dermatitis seboroik $\quad(p=0,015 ; \quad P R=10,385), \quad$ frekuensi mengganti handuk 5 haris sekali signifikan terhadap terjadinya dermatitis seboroik $(p=0,040 ; \quad P R=4,600), \quad$ penggunaan sisir bergantian signifikan terhadap terjadinya dermatitis seboroik $(p=0,029 ; P R=5,222)$, dan cara menyimpan hijab yang kurang terkena 
cahaya signifikan terhadap terjadinya dermatitis seboroik ( $\mathrm{p}=0,035 ; \mathrm{PR}=6,182)$ (tabel 2).

\section{b. Analisis Multivariat}

Analisis multivariat dilakukan untuk melihat hubungan variabel bebas mana yang paling erat dengan variabel terikat. Dari hasil analisis multivariat didapatkan variabel hasil penggunaan handuk, frekuensi mengganti handuk dan cara menyimpan hijab merupakan variabel yang signifikan terhadap terjadinya dermatitis seboroik (tabel 2). Sedangkan faktor sampel keramas setiap minggu, berganti-ganti shampoo, menggunakan sisir bergantian dan frekuensi mengganti hijab tidak signifikan terhadap terjadinya dermatitis seboroik.
Dari hasil analisis multivariat (tabel 2) didapatkan hasil bahwa penggunaan handuk signifikan terhadap terjadinya dermatitis seboroik $(p=0,016 ; \quad P R=30,840 ; \quad B=3,429)$, penggunaan handuk secara bergantian lebih berpengaruh terhadap terjadinya dermatitis seboroik dibandingkan dengan penggunaan handuk sendiri (tanpa bergantian). Frekuensi mengganti handuk signifikan terhadap terjadinya dermatitis seboroik $\quad(p=0,022 ; \quad P R=14,554$; $\mathrm{B}=2,678)$, mengganti handuk 5 hari sekali lebih berpengaruh terhadap kejadian dermatitis seboroik. Cara menyimpan hijab signifikan terhadap terjadinya dermatitis seboroik $(p=0,018 ; \quad P R=16,921 ; \quad B=2,829)$, menyimpan hijab kurang terkena cahaya lebih berpengaruh terhadap terjadinya dermatitis seboroik.

Tabel 1. Karakteristik sampel Dermatitis Seboroik di SMA Muhammadiyah 1 Semarang

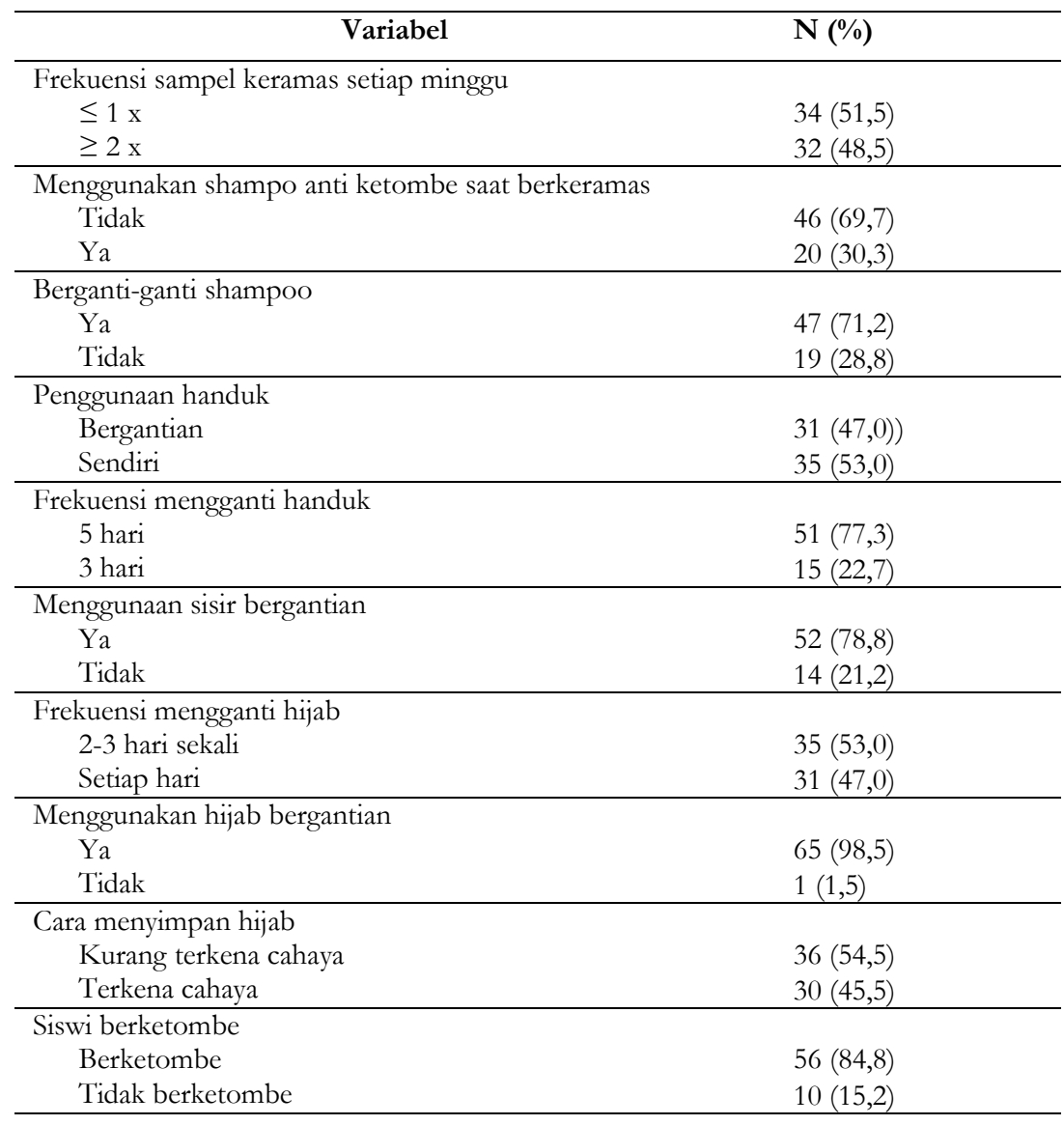


Tabel 2. Analisis bivariat dan multivariat perawatan rambut terhadap kejadian dermatitis seboroik di SMA Muhammadiyah 1 Semarang

\begin{tabular}{|c|c|c|c|c|c|c|c|}
\hline \multirow{2}{*}{ Variabel } & \multicolumn{3}{|c|}{ Dermatitis Seboroik } & \multicolumn{2}{|l|}{ Bivariat } & \multicolumn{2}{|l|}{ Multivariat } \\
\hline & $\begin{array}{l}\mathrm{Ya} \\
\mathrm{n}(\%)\end{array}$ & $\begin{array}{l}\text { Tidak } \\
\mathrm{n}(\%)\end{array}$ & $\mathrm{P}$ value & PR & $\mathrm{P}$ value & PR & $\beta$ \\
\hline \multicolumn{8}{|c|}{ Frekuensi sampel keramas setiap minggu } \\
\hline$\leq 1 \mathrm{x}$ & $32(94,1)$ & $2(5,9)$ & $0,041^{¥ *}$ & 5,333 & 0,241 & 3,023 & 1,106 \\
\hline$\geq 2 \times$ & $24(75,0)$ & $8(25,0)$ & & & & & \\
\hline \multicolumn{8}{|c|}{ Menggunakan shampo anti ketombe saat berkeramas } \\
\hline Tidak & $36(78,3)$ & $10(21,7)$ & $0,026^{¥ *}$ & - & - & - & - \\
\hline $\mathrm{Ya}$ & $20(100,0)$ & $0(0)$ & & & & & \\
\hline \multicolumn{8}{|l|}{ Berganti-ganti shampoo } \\
\hline $\mathrm{Ya}$ & $43(91,5)$ & $4(8,5)$ & $0,027^{¥ *}$ & 4,962 & 0,262 & 2,873 & 1,055 \\
\hline Tidak & $13(68,4)$ & $6(31,6)$ & & & & & \\
\hline \multicolumn{8}{|l|}{ Penggunaan handuk } \\
\hline Bergantian & $30(96,8)$ & $1(3,2)$ & $0,015^{¥ *}$ & 10,385 & 0,016 & 30,840 & 3,429 \\
\hline Sendiri & $26(74,3)$ & $9(25,7)$ & & & & & \\
\hline \multicolumn{8}{|l|}{ Frekuensi mengganti handuk } \\
\hline 5 hari & $46(90,2)$ & $5(9,8)$ & $0,040^{¥ *}$ & 4,600 & 0,022 & 14,554 & 2,678 \\
\hline 3 hari & $10(66,7)$ & $5(33,3)$ & & & & & \\
\hline \multicolumn{8}{|l|}{ Menggunaan sisir bergantian } \\
\hline $\mathrm{Ya}$ & $47(90,4)$ & $5(9,6)$ & $0,029^{¥ *}$ & 5,222 & 0,860 & 1,245 & 0,219 \\
\hline Tidak & $9(64,3)$ & $5(35,7)$ & & & & & \\
\hline \multicolumn{8}{|l|}{ Frekuensi mengganti hijab } \\
\hline 2-3 hari sekali & $29(82,9)$ & $6(17,1)$ & $0,739^{¥}$ & 1,397 & 0,848 & 1,177 & 0,163 \\
\hline Setiap hari & $27(87,1)$ & $4(12,9)$ & & & & & \\
\hline \multicolumn{8}{|c|}{ Menggunakan hijab bergantian } \\
\hline $\mathrm{Ya}$ & $55(84,6)$ & $10(15,4)$ & $1,000^{¥}$ & - & - & - & - \\
\hline Tidak & $1(100,0)$ & $0(0)$ & & & & & \\
\hline \multicolumn{8}{|l|}{ Cara menyimpan hijab } \\
\hline Kurang terkena cahaya & $34(94,4)$ & $2(5,6)$ & $0,035^{¥ *}$ & 6,182 & 0,018 & 16,921 & 2,829 \\
\hline Terkena cahaya & $22(73,3)$ & $8(26,7)$ & & & & & \\
\hline
\end{tabular}

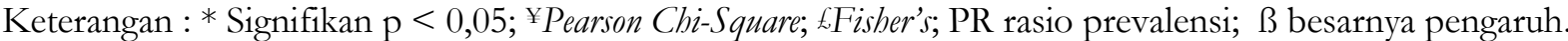




\section{PEMBAHASAN}

Berdasarkan keseluruhan sampel yang dilakukan pada penelitian, sebagian besar sampel mengalami dermatitis seboroik (84,8\%). Terdapat beberapa faktor yang menyebabkan dermatitis seboroik, yaitu kolonisasi Malassezia.sp, peningkatan produksi sebum dan faktor predisposisi pada individu.(5) Hasil ini serupa dengan penelitian terdahulu yang menyatakan bahwa dermatitis seboroik meningkat pada usia remaja. Hal ini dikarenakan meningkatnya aktivitas fisik di usia remaja yang berdampak pada peningkatan produksi sebum sehingga mengakibatkan peningkatan aktivitas mikroflora khususnya Malasseria sp pada kulit kepala.(10) Malassezia sp merupakan flora normal pada kulit kepala yang berperan pada kelainan kulit kepala, salah satunya dermatitis seboroik jika dalam jumlah berlebih.(11)

Permasalahan pada pengguna hijab dapat terjadi karena sikap yang erat kaitannya dengan kelembapan dan panas akibat pola perawatan rambut yang salah dan penggunaan hijab yang tidak benar.(6) Penggunaan hijab dapat ikut berperan dalam meningkatkan kelembapan daerah kepala sehingga meningkatkan kejadian dermatitis seboroik. Hal ini disebabkan mikroorganisme penyebab dermatitis seboroik dapat berkembang dengan baik pada kondisi kepala yang lembab.(12) Beberapa faktor yang dapat mempengaruhi kesehatan kulit kepala, diantaranya adalah stres lingkungan, misalnya iklim, musim, kolonisasi mikroba dan perubahan hormonal.(7)

Terjadinya dermatitis seboroik pada siswi SMA Muhammadiyah 1 Semarang termasuk tinggi dari data ini diperkuat dengan data dari
International Date Base, US Sensus Bureau tahun 2004 yang menyatakan bahwa $>43$ juta jiwa masyarakat Indonesia menderita dermatitis seboroik dan menempati urutan ke empat tertinggi setelah China, India, dan US. ${ }^{(13,14)}$

Dari hasil kuesioner higiene perorangan dan pemeriksaan secara langsung dapat dianalisis kembali satu per satu terhadap kejadian dermatitis seboroik diantaranya frekuensi keramas setiap minggu, keramas dengan shampoo, berganti-ganti shampoo, penggunaan handuk, frekuensi mengganti handuk, penggunakan sisir bergantian, frekuensi mengganti hijab, penggunakan hijab bergantian, dan cara menyimpan hijab.

Dari hasil analisis multivariat didapatkan hanya 3 faktor yang signifikan yaitu penggunaan handuk, frekuensi mengganti handuk dan cara menyimpan hijab yang bermakna sehingga dapat diketahui faktor faktor yang dominan terhadap terjadinya dermatitis seboroik, sedangkan pada analisis bivariat didapatkan faktor frekuensi sampel keramas setiap minggu, menggunakan shampo saat berkeramas, berganti-ganti shampo, penggunaan handuk, frekuensi mengganti handuk, menggunakan sisir bergantian dan cara menyimpan hijab merupakan faktor yang signifikan. Untuk hasil yang tidak signifikan didapatkan pada beberapa faktor diantaranya menggunakan shampo saat berkeramas, frekuensi mengganti hijab dan menggunakan hijab bergantian.

Cara menyimpan hijab signifikan terhadap terjadinya dermatitis seboroik, menyimpan hijab kurang terkena cahaya lebih berpengaruh terhadap terjadinya dermatitis seboroik. Hal ini tidak sesuai dengan penelitian yang dilakukan oleh Istiqomah MI, dkk yang menyatakan bahwa 
tempat penyimpanan penutup kepala bukan merupakan faktor risiko terjadinya dermatitis seboroik. (15) Hasil ini menjelaskan bahwa tempat penyimpanan hijab merupakan faktor risiko terhadap kejadian dermatitis seboroik. Berdasarkan teori yang sesuai dari $\mathrm{S}$ Ranganathan, dkk bahwa Malasseziia sp tumbuh secara baik pada media yang lembab dan lingkungan yang kaya keringat. ${ }^{(13)}$

Dari penggunaan handuk dan frekuensi mengganti handuk berpengaruh terhadap terjadinya dermatitis seboroik. Hal ini berbeda dengan penelitian sebelumnya yang dilakukan oleh Istiqomah MI, dkk yang menyatakan kedua faktor tersebut tidak menunjukkan hasil berpengaruh terhadap kejadian dermatitis seboroik.(15) Penelitian ini sesuai dengan teori Hanan Shehata, dkk bahwa dermatitis seboroik dapat dipicu salah satunya oleh kebersihan yang buruk.(16) Kebersihan rambut harus dijaga dengan mencuci rambut sekurang-kurangnya 2 kali seminggu, mencuci rambut memakai shampoo atau bahan pencuci rambut lainnya, dan sebaiknya menggunakan alat-alat pemeliharaan rambut sendiri.(17)

Faktor frekuensi sampel keramas setiap minggu, berganti-ganti shampo dan menggunakan sisir bergantian merupakan variabel yang signifikan pada analisis bivariat, namun tidak signifikan pada analisis multivariat. Hal ini serupa dengan penelitian yang dilakukan oleh Istiqomah MI, dkk yang menunjukkan faktor frekuensi sampel keramas setiap minggu, berganti-ganti shampo dan menggunakan sisir bergantian tidak signifikan terhadap dermatitis seboroik.(15) Hasil penelitian berbeda dengan teori yang menyatakan bahwa higiene perorangan yang kurang baik berpengaruh pada kejadian dermatitis seboroik. ${ }^{(18)}$

Beberapa faktor yang tidak signifikan pada analisis bivariat adalah menggunakan shampo saat keramas, frekuensi mengganti hijab dan menggunakan hijab bergantian. Hasil ini serupa dengan penelitian sebelumnya yang menyatakan bahwa menggunakan shampo saat keramas, frekuensi mengganti hijab dan menggunakan hijab bergantian tidak signifikan terhadap terjadinya dermatitis seboroik. ${ }^{(15,18)}$

Penggunaan hijab pada dasarnya bukanlah menjadi penyebab dari terganggunya kesehatan rambut, namun sikap dalam menjaga kesehatan rambutlah yang harus diperhatikan karena dapat menjadi penyebab munculnya permasalahan rambut. $(8,9)$

\section{KESIMPULAN DAN SARAN}

Faktor hubungan perilaku perawatan rambut yang meliputi penggunaan handuk, frekuensi mengganti handuk dan cara menyimpan hijab berpengaruh terhadap terjadinya dermatitis seboroik. Hal ini kemungkinan dikarenakan akibat kurangnya higiene perorangan pada kelompok sampel.

\section{DAFTAR PUSTAKA}

1. Clavaud C, Jourdain R, Bar-Hen A, Tichit M, Bouchier C, Pouradier F, et al. Dandruff Is Associated with Disequilibrium in the Proportion of the Major Bacterial and Fungal Populations Colonizing the Scalp. PLoS One. 2013;8(3).

2. Schwartz RA, Janusz CA, Janniger CK. Seborrheic dermatitis: An overview. Vol. 
74, American Family Physician. 2006. p. 125-30.

3. Gupta AK, Bluhm R. Seborrheic dermatitis. J Eur Acad Dermatol Venereol. 2004;18(1):13-26-20.

4. Ismail Muhamad, Azman Che Mat. Memaknakan Terjemahan Frasa Sendi Bahasa Arab ke Bahasa Melayu Berdasarkan Ilmu Sintaksis-semantik. Islamiyyat. 2010;32:115-34.

5. Nenoff P, Haustein UF, Hittel N. Activity of nadifloxacin (OPC-7251) and seven other antimicrobial agents against aerobic and anaerobic Gram-positive bacteria isolated from bacterial skin infections. Chemotherapy. 2004;50(4):196-201.

6. Badan Pusat Statistik. Sensus Penduduk 2010 - Penduduk Menurut Wilayah dan Agama yang Dianut [Internet]. Badan Pusat Statistik. 2010. Available from:http://sp2010.bps.go.id/index.php / site $/$ tabel? wid $=0000000000 \&$ tid $=321 \&$ fi $1=57 \& f i 2=3$

7. Robbins CR. Chemical Composition of Different Hair Types. In: Chemical and Physical Behaviour of Human Hair [Internet]. 2002. p. xvii, 483 . Available from:

http://www.loc.gov/catdir/enhancemen ts/fy0814/00059475-

d.html\%5Cnhttp://www.loc.gov/catdir/ enhancements / fy0814/00059475t.html\%5Cnhttp://www.springerlink.co $\mathrm{m} /$ index/10.1007/978-3-642-25611-0
8. Mitsui T. New CMitsui, T. New Cosmetic Science. Elsevier. http://doi.org/10.1007/s13398-0140173-7.2osmetic Science. Elsevier. 1997.

9. Jassem ZA, Jassem JA. Abdullah Yusuf Ali?s Translation Of The Quran: An Evaluation. Masal Pendidik [Internet]. 2001;24:29-52. Available from: http:/ / myais.fsktm.um.edu.my/5133/

10. Ro BI, Dawson TL. The role of sebaceous gland activity and scalp microfloral metabolism in the etiology of seborrheic dermatitis and dandruff. J Investig Dermatol Symp Proc [Internet]. 2005;10(3):194-7. Available from: http://www.sciencedirect.com/science/a rticle/pii/S0022202X15525864

11. Thomas D, Christina G, Yvonne D, Joseph K. Dandruff and seborrheic dermatitis likely result from scalp barrier breach and irritation induced by Malassezia metabolites, particularly free fatty acids. Am Acad Dermatology. 2005;52(3):49.

12. Dawson TL. Malassezia globosa and restricta: Breakthrough Understanding of the Etiology and Treatment of Dandruff and Seborrheic Dermatitis through Whole-Genome Analysis. J Investig Dermatology Symp Proc [Internet]. 2007;12(2):15-9. Available from: http://dx.doi.org/10.1038/sj.jidsymp.56 50049

13. Ranganathan S, Mukhopadhyay $T$. Dandruff: The most commercially 
84 Bevi Ayu, et al.

exploited skin disease. Indian J Dermatol [Internet]. 2010;55(2):130. Available from: http://www.eijd.org/text.asp?2010/55/2/130/62734

14. Borda LJ, Wikramanayake TC. Seborrheic Dermatitis and Dandruff: A Comprehensive Review. J Clin Investig dermatology [Internet]. 2015;3(2):147790. Available from: http://www.ncbi.nlm.nih.gov/pubmed/ 27148560\%5Cnhttp://www.pubmedcent ral.nih.gov/articlerender.fcgi? artid=PMC 4852869

15. Istiqomah MI, Subchan $\mathrm{P}, \mathrm{S}$ AW.
Prevalensi dan faktor risiko terjadinya ketombe pada polisi lalu lintas kota semarang. 2016;5(4):1276-83.

16. Journal LS, Guidelines N, Symptoms HD, Mohamed HS, Farahat NH, Megallaa NG, et al. 2014;11:323-33.

17. Zarei-Mahmoudabadi A, Zarrin M, Mehdinezhad F. Seborrheic dermatitis due to Malassezia species in Ahvaz, Iran. Iran J Microbiol. 2013;5(3):268-71.

18. Mustofa A. Prevalensi Dan Faktor Resiko Terjadinya Pityriasis Versicolor Pada Polisi Lalu Lintas Kota Semarang. 2014;4(5):45-50. 